\title{
A NEW FAMILY OF WEIGHTED OPERATOR MEANS INCLUDING THE WEIGHTED HERON, LOGARITHMIC AND HEINZ MEANS
}

\author{
MASATOSHI ITO
}

Abstract. The weighted power and Heron means are well known as generalizations of the weighted arithmetic, geometric and harmonic ones, and also some researchers investigate weighted means except them. Recently, Pal, Singh, Moslehian and Aujla introduced the weighted logarithmic mean of two positive numbers or operators.

In this paper, we propose the notion of a transpose symmetric path of weighted $\mathfrak{M}$-means for a symmetric operator mean $\mathfrak{M}$, and we introduce a new family of operator means including the weighted logarithmic mean by Pal et al.. This family newly produces the weighted Heinz mean. Moreover we obtain some relations among the weighted Heron, logarithmic and Heinz means.

Mathematics subject classification (2010): 47A64, 47A63, 26E60.

Keywords and phrases: Logarithmic mean, Heinz mean, Heron mean, operator mean and transpose symmetric path of weighted $\mathfrak{M}$-means.

\section{REFERENCES}

[1] J. I. FUJII, Interpolationality for symmetric operator means, Sci. Math. Jpn, 75 (2012), 267-274.

[2] J. I. FUJII AND E. KAMEI, Uhlmann's interpolational method for operator means, Math. Japon., 34 (1989), 541-547.

[3] J. I. FujII AND Y. SEO, On parameterized operator means dominated by power ones, Sci. Math., 1 (1998), 301-306.

[4] T. FURUTA, Concrete examples of operator monotone functions obtained by an elementary method without appealing to Löwner integral representation, Linear Algebra Appl., 429 (2008), 972-980.

[5] F. HiAi AND H. KosAKI, Means for matrices and comparison of their norms, Indiana Univ. Math. J., 48 (1999), 899-936.

[6] M. ITo, Estimations of power difference mean by Heron mean, J. Math. Inequal., 11 (2017), 831-843.

[7] M. ITO, Estimations of the weighted power mean by the Heron mean and related inequalities for determinants and traces, to appear in Math. Inequal. Appl..

[8] F. Kubo And T. Ando, Means of positive linear operators, Math. Ann., 246 (1980), $205-224$.

[9] E. Neuman, The weighted logarithmic mean, J. Math. Anal. Appl., 188 (1994),885-900.

[10] R. Pal, M. Singh, M. S. Moslehian And J. S. Aujla, A new class of operator monotone functions via operator means, Linear Multilinear Algebra, 64 (2016), 2463-2473.

[11] M. PÁLFIA AND D. PETZ, Weighted multivariable operator means of positive definite operators, Linear Algebra Appl., 463 (2014), 134-153.

[12] J. PeČARIĆ, T. FurutA, J. Mićić Hot AND Y. SEO, Mond-Pečarić method in operator inequalities, Monographs in Inequalities 1, Element, Zagreb, 2005.

[13] M. RAÏSsouli, Parameterized logarithm mean, Int. J. Math. Anal. (Ruse), 6 (2012), 863-869.

[14] M. RaÏssouli And J. SÁndor, On a class of new means including the generalized SchwabBorchardt mean, J. Inequal. Appl. 2017, Paper No. 136, 28 pp.

[15] M. UCHIYAma, A new majorization between functions, polynomials, and operator inequalities, J. Funct. Anal., 231 (2006), 221-244.

[16] Y. UdAGAWA, T. YAMAZAKI AND M. YANAGIDA, Some properties of weighted operator means and characterizations of interpolational means, Linear Algebra Appl., 517 (2017), 217-234. 
[17] S. WU AND L. Debnath, Inequalities for differences of power means in two variables, Anal. Math., 37 (2011), 151-159.

[18] W.-F. XIA, S.-W. Hou, G.-D. Wang AND Y.-M. ChU, Optimal one-parameter mean bounds for the convex combination of arithmetic and geometric means, J. Appl. Anal., 18 (2012), 197-207. 